doi: $10.2306 /$ scienceasia1513-1874.2012.38.364

\title{
Rice straw and sugarcane bagasse degradation mimicking lignocellulose decay in nature: An alternative approach to biorefinery
}

\author{
Chularat Sakdaronnarong*, Woranart Jonglertjunya \\ Department of Chemical Engineering, Faculty of Engineering, Mahidol University, \\ 25/25 Putthamonthon 4 Road, Salaya, Nakhon Pathom 73170 Thailand \\ *Corresponding author, e-mail: chularat.sak@mahidol.ac.th
}

Received 9 Mar 2012

Accepted 10 Oct 2012

\begin{abstract}
Rice straw (Oryza sativa) and sugarcane bagasse (Saccharum spp.) were subjected to catalytic oxidation. An oxidative cleavage of lignocellulose agro-residues was based on ferric ions and hydrogen peroxide driven by 2,5dihydroxybenzoic acid (DHB) in weak acidic condition at room temperature. Alteration of inter- and intra-molecular bonding of cellulose and change in cellulose crystallinity which led to influence enzymatic susceptibility were investigated. By means of Fourier transform infrared spectroscopy, functional groups and chemical bonding modification in cellulosic, non-cellulosic, and lignin constituents of rice straw and sugarcane bagasse were characterized. Transformation of crystalline cellulose $\mathrm{I}_{\alpha}$ and $\mathrm{I}_{\beta}$ forms was observed after the oxidative reaction. The catalytic oxidative reaction by the $\mathrm{Fe}^{3+} / \mathrm{DHB} / \mathrm{H}_{2} \mathrm{O}_{2}$ system accelerated the modification of cellulose $I_{\alpha}$ to cellulose $I_{\beta}$ phase of sugarcane bagasse. However, the addition of DHB barely affected the oxidative degradation of rice straw. In addition, the crystallinity index of rice straw and sugarcane bagasse that decreased after oxidative reaction caused increases of hydrolytic enzyme accessibilities of treated samples.
\end{abstract}

KEYWORDS: biomass, catalytic oxidative degradation, X-ray diffraction, crystallinity index, SEM

\section{INTRODUCTION}

Rice straw and sugarcane bagasse are abundant agroresidues in Thailand. Rice straw contains approximately $30-35 \%$ cellulose, $25-30 \%$ hemicellulose, 15-28\% lignin, and $4-7 \%$ ashes $^{1}$. A little higher content of lignin and lower amount of carbohydrates (hemicellulose + cellulose) are found in sugarcane bagasse, i.e., 32-43\% cellulose, 19-24\% hemicellulose, $25-32 \%$ total lignin, 6-12\% extractives, and 2$6 \% \mathrm{ash}^{2-4}$. Cellulose and hemicelluloses from these lignocellulosic materials are considered as potent precursors for the second generation biofuels and biobased materials production generated by the so-called biorefinery processes. However, biological use and chemical fractionation of these lignocellulosic materials are limited due to their complex matrix as well as degrees of lignification, acetylation and crystallinity of the material ${ }^{5,6}$.

Wood decay in nature has been studied as ideal mechanistic models for in vitro lignocelluloses degradation. It is known that early stages of the decay process occur without participation of enzymes, because even the smallest enzymes are too large to penetrate the pores of the sound wood ${ }^{7}$. Thus it has been proposed that non-enzymatic oxidative mechanisms take place in brown-rotting in which cellulose and hemicelluloses were substantially degraded ${ }^{8,9}$. Wood biodegradation naturally takes place with participation of iron and chelating compounds such as phenolic acids and lipid metabolites from fungi which are present in high amount in native decaying wood $^{8}$. Chelated ferric ions generated highly active radicals play an important part in degradation of hemicellulose and cellulosic moieties in weak acidic condition ${ }^{8,10-12}$ by a mechanism called Fenton-based reaction. Apart from carbohydrate degradation, lignin and some other recalcitrant compounds can be oxidized and degraded via oxidative reactions using native fungi as well as alkali-peroxide and alkaline nitrobenzene oxidation $^{13-15}$.

Fenton-based reaction has takes place in cellulose biodegradation by brown-rot fungi in nature by either cellulose modification and degradation or cellulose crystallinity reduction. Fenton reaction occurs between a mixture of oxidants, e.g., hydrogen peroxide and ferrous ions, and the reaction between these two components furnishes a source of hydroxyl radicals $\left(\mathrm{Fe}^{2+}+\mathrm{H}_{2} \mathrm{O}_{2} \longrightarrow \mathrm{Fe}^{3+}+\mathrm{OH}^{-}+{ }^{\circ} \mathrm{OH}\right)$. Highly reactive radicals generated are able to degrade and de- 
polymerize a wide range of substrates ${ }^{8-11}$. Mediators have been taken into account on reducing ferric ions $\left(\mathrm{Fe}^{3+}\right)$ to ferrous ions $\left(\mathrm{Fe}^{2+}\right)$ so that iron acts catalytically and an oxidative reaction is continually carried on. Mediators or chelating agents used for studies of catalytic degradation of lignocellulosic model compounds by Fenton reaction comprise: oxalate, GT chelator, catechol, gallic acid, 2,3-dihydroxybenzoic acid (2,3-DHBA), deferroxamine, ethylenediaminetetraacetic acid (EDTA), diethylenetetramine (DTPA), pentaacetic acid, and nitrylotriacetic acid (NTA) ${ }^{12,16}$.

Native cellulose fibrils orientation (cellulose I) is categorized into the $\mathrm{I}_{\alpha}$ and $\mathrm{I}_{\beta}$ phases on the basis of the appearance of the $\mathrm{OH}$ stretching region of their infrared spectra ${ }^{17,18}$. It has been suggested that hydrogen bonding patterns within the crystalline domains partially caused the differences between these two phases of native cellulose I. Metastable crystalline cellulose $I_{\alpha}$ form became allomorph cellulose $I_{\beta}$ after heat treatment at $260-280^{\circ} \mathrm{C}$ in alkali solution ${ }^{19,20}$. The present work aimed to investigate the influence of non-enzymatic oxidative reaction that mimics wood decay in nature on lignocellulose degradation or modification. Changes in crystallinity index, enzymatic solubilization as well as chemical composition and structural changes of rice straw and sugarcane bagasse after oxidative degradation were discussed herein.

\section{MATERIALS AND METHODS}

\section{Materials}

Rice straw (Oryza sativa) was obtained from a local field in Nakornchaisri, Nakhon Pathom province, Thailand. Sugarcane bagasse (Saccharum spp.) was contributed from Khonburi Sugar Co. Ltd., Thailand. Iron mediators, namely 2,5-dihydroxybenzoic acid (DHB), trans-4-hydroxy-3-methoxycinnamic acid (ferulic acid), 4-hydroxy-3,5-dimethoxybenzoic acid (syringic acid), oxalic acid, 1,2-dihydroxybenzene (catechol), and ethylenediaminetetraacetic acid (EDTA), were purchased from Fluka and SigmaAldrich. Chemicals for experiments and analyses were analytical grade from Fluka, Sigma-Aldrich, and Ajax Finechem.

\section{Screening of mediators on ferric-to-ferrous reducing capacity}

The reduction capacity of iron mediators was performed in 1-ml microtubes. Reaction mixture contained $0.015 \mathrm{ml}$ of $0.1 \mathrm{M} \mathrm{FeCl}_{3} 6 \mathrm{H}_{2} \mathrm{O}, 0.01 \mathrm{ml}$ of $0.1 \mathrm{M}$ mediator, $0.5 \mathrm{ml}$ deionized water, and $0.475 \mathrm{ml}$ of $0.03 \mathrm{M}$ sodium acetate buffer $\mathrm{pH}$ 4.5. $\mathrm{Fe}^{2+}$ concentration from the reduction of $\mathrm{Fe}^{3+}$ by each mediator was determined by complexation with $0.5 \mathrm{ml}$ of $1 \%(\mathrm{w} / \mathrm{v})$ ferrozine. After 1-min complexation, fully colour development (absorbance at $562 \mathrm{~nm}$ ) was measured kinetically (the molar absorptivity, $\left.\varepsilon_{562 \mathrm{~nm}}=27900 \mathrm{M}^{-1} \mathrm{~cm}^{-1}\right)^{21}$ from 0-30 min with a UV-Vis spectrophotometer (Spectronic 1001, Milton Roy, USA). The control reaction was performed without mediator and the volume was replaced by deionized water. Actual $\mathrm{Fe}^{2+}$ concentration was calculated after subtraction from the control.

\section{Oxidative degradation of lignocelluloses}

Rice straw and sugarcane bagasse were chopped to $1.0-1.5 \mathrm{~cm}$-length. The oxidative reaction was carried out in a 500-ml Erlenmeyer flask containing $10 \mathrm{~g}$ rice straw or sugarcane bagasse (dry weight), $0.2 \mathrm{M} \mathrm{H}_{2} \mathrm{O}_{2}, 1 \mathrm{mM} \mathrm{FeCl} \mathrm{F}_{3} \cdot 6 \mathrm{H}_{2} \mathrm{O}$ and $0.1 \mathrm{mM}$ 2,5-dihydroxybenzoic acid (DHB). Final volume of $200 \mathrm{ml}$ was adjusted by adding deionized water. Subsequently, $1 \mathrm{M} \mathrm{NaOH}$ and conc. $\mathrm{H}_{2} \mathrm{SO}_{4}$ were used to adjust the $\mathrm{pH}$ to 3.0 and after that reaction took place at ambient temperature $\left(30^{\circ} \mathrm{C}\right)$ for $4 \mathrm{~h}$. Control experiments were conducted simultaneously namely (1) $\mathrm{Fe}^{3+} / \mathrm{H}_{2} \mathrm{O}_{2}$ without DHB, (2) $\mathrm{H}_{2} \mathrm{O}_{2}$ without $\mathrm{Fe}^{3+}$ and DHB, and (3) blank (only acidic solution). Pretreated straw and bagasse samples were washed afterwards with 11 deionized water. Then, $3 \mathrm{~g}$ of pretreated samples (wet basis) were kept at $-20^{\circ} \mathrm{C}$ for enzymatic hydrolysis. The rest was dried at $50^{\circ} \mathrm{C}$ for 2-3 days for analysis of weight loss, cellulose content, FTIR spectroscopy, and carboxyl content.

\section{Weight loss and enzymatic solubilization}

Weight loss of pretreated lignocelluloses after oxidative reaction was calculated after drying at $50^{\circ} \mathrm{C}$ for 2-3 days compared with initial dry weight of samples. Determination of polysaccharide solubilization was performed in a 50-ml Erlenmeyer flask consisting of $100 \mathrm{mg}$ (dry weight) of pretreated lignocellulose and $320 \mathrm{FPU} / \mathrm{g}$ substrate of Accellerase 1500 (www. genencor.com). The total volume of solution was adjusted to $10 \mathrm{ml}$ by addition of $0.05 \mathrm{M}$ sodium-acetate buffer $\mathrm{pH}$ 4.8. Enzymatic hydrolysis was performed in an orbital shaker at $50^{\circ} \mathrm{C}$ for $48 \mathrm{~h}$. The content of reducing sugars solubilized into hydrolysate was determined by modified dinitrosalicylic acid (DNS) assay $^{22}$. The colour development was measured by UV-Vis spectroscopy at $575 \mathrm{~nm}$ (Spectronic 1001, Milton Roy, USA). Reducing sugars released from pretreated samples were reported as glucose equivalence. Percentage of enzymatic solubilization of pretreated lignocellulosic materials was calculated as 
(162/180)(amount of glucose produced)/(amount of substrate).

\section{Holocellulose and alpha-cellulose contents}

Holocellulose and alpha-cellulose contents of untreated and chemically treated samples were analysed according to Wise and Addieco's procedure ${ }^{23}$ and TAPPI Method T203 om- $83^{24}$, respectively.

\section{Analysis of carboxyl content}

To determine the carboxyl content, $0.5 \mathrm{~g}$ of the sample was dispersed in $50 \mathrm{ml}$ of $2 \%(\mathrm{w} / \mathrm{w})$ calcium acetate solution for $30 \mathrm{~min}$. Subsequently, the suspension was titrated with standardized $0.1 \mathrm{~N} \mathrm{NaOH}$ solution using phenolphthalein as an indicator. The actual volume of $\mathrm{NaOH}$ consumed was corrected with the blank. Finally, carboxyl content was calculated as $(N V m) /\left(\right.$ mass of the sample) ${ }^{25}$ where $N, V$, and $m$ are normality, volume, and molecular mass of $\mathrm{NaOH}$, respectively.

\section{Fourier transform infrared (FTIR) spectroscopy}

Treated rice straw and sugarcane bagasse samples were dried at $50^{\circ} \mathrm{C}$ for $48 \mathrm{~h}$ and ground to $250 \mu \mathrm{m}$ and then mixed with $\mathrm{KBr}$ (sample : $\mathrm{KBr}$ of 1:99) to form a disc. FTIR spectroscopy of a $\mathrm{KBr}$ disc containing $1 \%$ finely ground sample was performed with four replicates in an absorbance mode in a range of 7800 to $370 \mathrm{~cm}^{-1}$ with 50 scans and $4 \mathrm{~cm}^{-1}$ resolution (Spectrum 2000, Perkin Elmer, Germany). An averaged spectrum was subsequently normalized at the peak $1060 \mathrm{~cm}^{-1}$ attributed to a CO stretching mode ${ }^{26}$. The dissimilarity between cellulose $I_{\alpha}$ and $\mathrm{I}_{\beta}$ crystalline phases was examined through the FTIR bands; $750 \mathrm{~cm}^{-1}$ for $I_{\alpha}$ and $710 \mathrm{~cm}^{-1}$ for $I_{\beta}$ phases ${ }^{12}$.

\section{X-ray diffraction}

A $70 \mathrm{mg}$ of ground sample $(250 \mu \mathrm{m})$ was pressed into a glass holder with applied pressure in a laboratory press. X-ray diffractometry was performed using Rigaku D/MAX 2200, Japan. X-ray diffractograms were recorded from $10^{\circ}$ to $50^{\circ}$ of $2 \theta$ (Bragg angle) by a goniometer equipped with a scintillation counter at a scanning speed of $0.05 \%$ and sampling rate of 5 data/s. Degree of crystallinity of cellulose was estimated according to the empirical method proposed by Segal et $\mathrm{al}^{27}$. The crystallinity index was defined as $\left(I_{002}-I_{\mathrm{Am}}\right) / I_{002}$, where $I_{002}$ is the intensity of diffraction at $2 \theta$ between $22^{\circ}$ and $23^{\circ}$ for cellulose I, and $I_{\mathrm{Am}}$ is the intensity, above the baseline, between the 020 and $110 / 110$ peaks of diffraction at $2 \theta$ between $18^{\circ}$ and $19^{\circ}$ representing amorphous part of lignocelluloses.

\section{Scanning electron microscope (SEM)}

Rice straw and sugarcane bagasse samples were mounted on metal stubs by double-faced tape. Dried samples were coated with a thin gold layer for $15 \mathrm{~min}$ in a vacuum chamber in order to improve the conductivity and prevent electron charging. SEM images were taken at $15 \mathrm{kV}$ (Hitachi S4800, Japan).

\section{RESULTS AND DISCUSSION}

\section{Screening of mediators on ferric-to-ferrous reducing capacity}

The proposed mechanisms of reaction between $\mathrm{Fe}^{3+}$ and mediators is:

$$
2 \mathrm{Fe}^{3+}+\text { mediator } \longrightarrow 2 \mathrm{Fe}^{2+}+\text { quinone derivative. }
$$

A subsequent step of Fenton reaction between $\mathrm{Fe}^{2+}$ and hydrogen peroxide $\left(\mathrm{H}_{2} \mathrm{O}_{2}\right)$ is:

$$
\mathrm{Fe}^{2+}+\mathrm{H}_{2} \mathrm{O}_{2} \longrightarrow \mathrm{Fe}^{3+}+\mathrm{OH}^{-}+{ }^{\cdot} \mathrm{OH} \text {. }
$$

Consequently, a suitable iron mediator powerfully lengthens the redox cyclic reaction by consecutively reducing $\mathrm{Fe}^{3+}$ and maintaining the reduced stage of iron, $\mathrm{Fe}^{2+}$, in the system, which subsequently reacts with hydrogen peroxide. Hydroxyl radicals generated from the oxidation of $\mathrm{Fe}^{2+}$ and $\mathrm{H}_{2} \mathrm{O}_{2}$ dramatically oxidize lignin and cellulosic compounds. This mechanism has been proposed as a biomimetic system of lignocellulose biodegradation at a site far from fungal hyphae during fungal decay at which non-enzymatic degradation is assumed to take place ${ }^{8,12}$.

Table 1 shows the influence of six iron mediators on reducing capability of $\mathrm{Fe}^{3+}$ to $\mathrm{Fe}^{2+}$. It was found that in a system containing an excess amount of $\mathrm{Fe}^{3+}$ $\left(0.5 \mathrm{mM} \mathrm{Fe}{ }^{3+}: 0.02 \mathrm{mM}\right.$ mediator), $1 \mathrm{~mol}$ of DHB produced $2 \mathrm{~mol}$ of $\mathrm{Fe}^{2+}$ according to the stoichiometry of equations. Similar results were reported when $2 \mathrm{~mol}$ of $\mathrm{Fe}^{3+}$ was reduced by $1 \mathrm{~mol}$ of mediator and produced $1 \mathrm{~mol}$ of a quinone derivative as shown above in equations (1) and (2) $)^{8,28,29}$.

As a result, only DHB yielded the theoretical iron reduction capacity according to the stoichiometry of the equations (1) and (2). The iron reduction activity of almost all reductants reached equilibrium condition in approximately $15 \mathrm{~min}$ (data not shown). On the other hand, $1 \mathrm{~mol}$ of catechol produced only $1.75 \mathrm{~mol}$ of $\mathrm{Fe}^{2+}$. This non-stoichiometric yield of catechol was proposed to occur through two-step mechanism ${ }^{30}$. The initial step involves the $\mathrm{Fe}^{3+}$-catechol complexation in the form of three catechol rings wrapping 
Table 1 Ferric-to-ferrous reducing capability of mediators $(500 \mu \mathrm{M}$ of $\mathrm{Fe}(\mathrm{III})$ and $20 \mu \mathrm{M}$ of mediator after $30 \mathrm{~min}$ reaction).

\begin{tabular}{lcc}
\hline Mediators & $\begin{array}{c}\mathrm{Fe}^{2+} \text { concentra- } \\
\text { tion }(\mu \mathrm{mol} / \mathrm{l})\end{array}$ & $\begin{array}{c}\mathrm{Fe}^{3+} \text { to } \mathrm{Fe}^{2+} \\
\text { conversion }(\%)^{\dagger}\end{array}$ \\
\hline $\begin{array}{l}\text { 2,5-dihydroxybenzoic acid } \\
\text { (DHB) }\end{array}$ & $40.46 \pm 1.55$ & 8.09 \\
$\begin{array}{l}\text { 1,2-dihydroxybenzene } \\
\text { (catechol) }\end{array}$ & $36.01 \pm 0.26$ & 7.20 \\
$\begin{array}{l}\text { Trans-4-hydroxy-3-methoxy- } \\
\text { cinnamic acid (ferulic acid) }\end{array}$ & $4.80 \pm 0.09$ & 0.96 \\
$\begin{array}{l}\text { 4-hydroxy-3,5-dimethoxy- } \\
\text { benzoic acid (syringic acid) }\end{array}$ & $6.71 \pm 0.43$ & 1.34 \\
$\begin{array}{l}\text { Oxalic acid } \\
\text { Ethylenediaminetetraacetic } \\
\text { acid (EDTA) }\end{array}$ & $0.15 \pm 0.03$ & 0.03 \\
\hline
\end{tabular}

Percentage of conversion was calculated based on initial $\mathrm{Fe}^{3+}$ concentration.

around the $\mathrm{Fe}^{3+}$ to afford a coordination propeller with the highest known binding constant for ferric ion $^{31}$. The complexes were subsequently oxidized and formed the quinone intermediate ${ }^{28}$ which was proposed to concurrently reduce $\mathrm{Fe}^{3+}$.

Among six mediators tested, DHB showed the highest iron reduction capability and catechol performed the second highest one. Syringic acid and ferulic acid gave moderate reduction capacity whereas EDTA and oxalic acid gave almost no iron reduction capability. Consequently, DHB was used as a mediator to investigate the effect of oxidative degradation on rice straw and sugarcane bagasse for the later experiments.

\section{Influence of oxidative reaction on chemical composition changes}

Weight loss, holo-cellulose, alpha-cellulose and residual lignin contents of oxidative pretreated rice straw and sugarcane bagasse by $\mathrm{Fe}^{3+} / \mathrm{DHB} / \mathrm{H}_{2} \mathrm{O}_{2}$ system were shown in Table 2. From the results, the strongest degradation indicated by weight losses was obtained when rice straw and sugarcane bagasse were subjected to the $\mathrm{Fe}^{3+} / \mathrm{DHB} / \mathrm{H}_{2} \mathrm{O}_{2}$ reaction. The oxidative degradation with $\mathrm{Fe}^{3+} / \mathrm{DHB} / \mathrm{H}_{2} \mathrm{O}_{2}$ yielded highest holocellulose content for sugarcane bagasse $(67.7 \% \mathrm{w} / \mathrm{w})$ whereas highest holocellulose yielded for rice straw was obtained from $\mathrm{Fe}^{3+} / \mathrm{H}_{2} \mathrm{O}_{2}$ in the absence of mediator $(71.0 \% \mathrm{w} / \mathrm{w})$, DHB. This evidence indicated that oxidative reaction caused modification and partial removal of lignin and other non-carbohydrate constituents similar to previous work ${ }^{3,4,32}$. Alphacellulose contents in all treatments of sugarcane bagasse were not significantly different but the maximum alpha-cellulose content was obtained from the blank for rice straw. As with holocellulose degra- dation, efficient reactions for delignification of sugarcane bagasse and rice straw yielding minimum residual lignin contents were $\mathrm{Fe}^{3+} / \mathrm{DHB} / \mathrm{H}_{2} \mathrm{O}_{2}$ and $\mathrm{Fe}^{3+} / \mathrm{H}_{2} \mathrm{O}_{2}, 16.2 \%$ and $15.8 \%$, respectively.

Moreover, enzymatic solubilization of rice straw (17.2\%) after non-enzymatic oxidative pretreatment was maximum when treated by $\mathrm{Fe}^{3+} / \mathrm{H}_{2} \mathrm{O}_{2}$ (Table 2). Most of enzymatic solubilization results were correlated to percentages of crystallinity. The lower degree of crystallinity yielded the higher extent of enzymatic solubilization. On the other hand, sugarcane bagasse treated by $\mathrm{Fe}^{3+} / \mathrm{DHB} / \mathrm{H}_{2} \mathrm{O}_{2}$ system achieved the utmost degree of enzymatic solubilization of polysaccharides (16.3\%) compared to that treated by $\mathrm{Fe}^{3+} / \mathrm{H}_{2} \mathrm{O}_{2}$ system and other controlled conditions. DHB gave no significant influence on oxidative degradation of rice straw. The reason was mainly due to considerable amount of phenolic compounds present derived from straw lignin during oxidative degradation, e.g., hydroxybenzaldehyde and vanillin from oxidation of $p$-coumaric acid and ferulic acid in straw lignin, respectively, as reported previously ${ }^{15,33}$. These compounds therefore assisted to accelerate Fenton-based reaction. Thus it was apparently not necessary to add DHB into the $\mathrm{Fe}^{3+} / \mathrm{H}_{2} \mathrm{O}_{2}$ oxidative pretreatment of rice straw whereas pretreatment of sugarcane bagasse required DHB to accelerate the reduction of $\mathrm{Fe}^{3+}$ to $\mathrm{Fe}^{2+}$ and lengthen the catalytic cycle during the oxidative reaction. Oxidative modification of rice straw and sugarcane bagasse was additionally observed by carboxyl content for the reactions containing $\mathrm{Fe}^{3+}$ and $\mathrm{H}_{2} \mathrm{O}_{2}$ compared with the controls and untreated ones (Table 2). Methylene groups of C6 in cellulose and hemicellulose moieties are oxidized by hydroxyl radical to form carboxylic groups. This result was in good agreement with a previous report where hemicelluloses in sugarcane bagasse were oxidized to form carboxylic acid by wet oxidation at $\mathrm{pH} 3$ for 5 and $15 \mathrm{~min}^{4}$. Although there were reported that this acid partially suppressed further biological steps for ethanol production; it was found that adding $\mathrm{Na}_{2} \mathrm{CO}_{3}$ assisted to decrease the formation of carboxylic acid during oxidation ${ }^{3,4}$.

\section{Cellulose modification assessed by FTIR spectroscopy}

FTIR spectroscopy has been widely performed as an effective tool to explain the alteration of chemical structure of lignocellulosic substrates. In the present work, all the absorbances were normalized at $1060 \mathrm{~cm}^{-1}$ attributed to $\mathrm{CO}$ stretching mode where non-cellulosic vibration bands are located $^{26}$. As shown in Fig. 1, oxidative degradation of aromatic 
Table 2 Experimental results of rice straw and sugarcane bagasse treated by oxidative degradation.

\begin{tabular}{|c|c|c|c|c|c|c|c|c|c|}
\hline \multirow{2}{*}{$\begin{array}{l}\text { Lignocellulosic } \\
\text { substrates }\end{array}$} & \multirow[t]{2}{*}{ Pretreatment } & \multicolumn{5}{|c|}{ Composition of treated substrate } & \multirow{2}{*}{$\begin{array}{c}\text { Enzyme } \\
\text { solubilization }\end{array}$} & \multirow{2}{*}{$\begin{array}{c}\text { Carboxyl } \\
\text { content }\end{array}$} & \multirow{2}{*}{$\begin{array}{c}\text { Crystallinity } \\
\text { index }\end{array}$} \\
\hline & & $\begin{array}{l}\text { Weight } \\
\text { loss } \\
(\% \mathrm{w} / \mathrm{w})\end{array}$ & $\begin{array}{l}\text { Holo- } \\
\text { cellulose } \\
(\% \mathrm{w} / \mathrm{w})\end{array}$ & $\begin{array}{l}\text { Alpha- } \\
\text { cellulose } \\
(\% \mathrm{w} / \mathrm{w})\end{array}$ & $\begin{array}{l}\text { Lignin } \\
(\% \mathrm{w} / \mathrm{w})\end{array}$ & $\begin{array}{l}\text { Others } \\
(\% \mathrm{w} / \mathrm{w})\end{array}$ & & & \\
\hline Rice straw & $\begin{array}{l}\mathrm{Fe}^{3+} / \mathrm{DHB} / \mathrm{H}_{2} \mathrm{O}_{2} \\
\mathrm{Fe}^{3+} / \mathrm{H}_{2} \mathrm{O}_{2} \\
\mathrm{H}_{2} \mathrm{O}_{2} \\
\text { Blank } \\
\text { Untreated }\end{array}$ & $\begin{array}{c}14.4 \pm 0.6 \\
13.1 \pm 0.5 \\
12.7 \pm 0.7 \\
11.0 \pm 0.4 \\
-\end{array}$ & $\begin{array}{l}60.5 \pm 0.9 \\
71.0 \pm 0.8 \\
70.7 \pm 0.7 \\
70.0 \pm 0.5 \\
70.2 \pm 0.5\end{array}$ & $\begin{array}{l}37.2 \pm 0.5 \\
37.3 \pm 0.4 \\
36.3 \pm 0.3 \\
39.0 \pm 0.5 \\
35.2 \pm 0.4\end{array}$ & $\begin{array}{l}17.2 \pm 0.4 \\
15.8 \pm 0.3 \\
17.5 \pm 0.2 \\
18.9 \pm 0.4 \\
20.5 \pm 0.5\end{array}$ & $\begin{array}{l}7.9 \\
0.1 \\
2.9 \\
0.1 \\
9.3\end{array}$ & $\begin{array}{l}12.6 \pm 0.4 \\
17.2 \pm 0.2 \\
14.5 \pm 0.2 \\
14.2 \pm 0.3 \\
10.4 \pm 0.4\end{array}$ & $\begin{array}{l}1.2 \pm 0.2 \\
1.9 \pm 0.1 \\
0.4 \pm 0.2 \\
0.3 \pm 0.2 \\
0.4 \pm 0.1\end{array}$ & $\begin{array}{l}28.5 \\
24.3 \\
35.2 \\
38.9 \\
37.7\end{array}$ \\
\hline $\begin{array}{l}\text { Sugarcane } \\
\text { bagasse }\end{array}$ & $\begin{array}{l}\mathrm{Fe}^{3+} / \mathrm{DHB} / \mathrm{H}_{2} \mathrm{O}_{2} \\
\mathrm{Fe}^{3+} / \mathrm{H}_{2} \mathrm{O}_{2} \\
\mathrm{H}_{2} \mathrm{O}_{2} \\
\text { Blank } \\
\text { Untreated }\end{array}$ & $\begin{array}{c}13.2 \pm 0.2 \\
12.6 \pm 0.1 \\
12.9 \pm 0.4 \\
10.7 \pm 0.3 \\
-\end{array}$ & $\begin{array}{l}67.7 \pm 0.6 \\
62.9 \pm 0.8 \\
64.8 \pm 0.4 \\
67.3 \pm 0.4 \\
66.8 \pm 0.5\end{array}$ & $\begin{array}{l}33.4 \pm 0.3 \\
33.3 \pm 0.1 \\
34.0 \pm 0.5 \\
33.2 \pm 0.4 \\
32.7 \pm 0.6\end{array}$ & $\begin{array}{l}16.2 \pm 0.3 \\
17.4 \pm 0.3 \\
17.9 \pm 0.1 \\
18.0 \pm 0.4 \\
21.3 \pm 0.6\end{array}$ & $\begin{array}{r}3.0 \\
7.1 \\
4.4 \\
4.0 \\
10.0\end{array}$ & $\begin{array}{r}16.3 \pm 0.3 \\
13.6 \pm 0.3 \\
11.4 \pm 0.4 \\
9.0 \pm 0.2 \\
9.5 \pm 0.3\end{array}$ & $\begin{array}{l}1.4 \pm 0.1 \\
1.1 \pm 0.1 \\
0.2 \pm 0.1 \\
0.2 \pm 0.2 \\
0.5 \pm 0.0\end{array}$ & $\begin{array}{l}30.8 \\
37.1 \\
41.8 \\
44.1 \\
44.4\end{array}$ \\
\hline
\end{tabular}

Compositions were calculated based on dry weight of pretreated substrate. Mean value \pm standard deviation of two replicates were reported.

$\mathrm{CH}$ assigned to lignin moieties was observed by an increase of absorption ratio of 1383: $1550 \mathrm{~cm}^{-1}$. The peak allocated at $1383 \mathrm{~cm}^{-1}$ was attributed to $\mathrm{C}-\mathrm{H}$ bending of cellulose and hemicelluloses ${ }^{34}$ and the peak near $1550 \mathrm{~cm}^{-1}$ was assigned to weak absorption of aromatic ring vibration of lignin ${ }^{35}$. For pretreated rice straw, relatively high absorption ratio of these two peaks was obtained after $\mathrm{Fe}^{3+} / \mathrm{H}_{2} \mathrm{O}_{2}$ pretreatment (Fig. 1a) indicating highest contents of cellulose and hemicellulose comparative to residual lignin content in treated material. This result was according to the holocellulose and lignin contents from wet-lab analysis shown in Table 2. The peak allocated near $898 \mathrm{~cm}^{-1}$ was attributed to absorption of $\beta-1,4$ glycosidic linkages indicating breakage degree of intramolecular hydrogen bonds ${ }^{34}$. Comparatively high absorption ratio of the peak 898: $850 \mathrm{~cm}^{-1}$ was obtained from both $\mathrm{Fe}^{3+} / \mathrm{H}_{2} \mathrm{O}_{2}$ treated rice straw (Fig. 1a) and $\mathrm{Fe}^{3+} / \mathrm{DHB} / \mathrm{H}_{2} \mathrm{O}_{2}$ treated sugarcane bagasse (Fig. 1b). This possibly suggested the elevated extent of polysaccharides which led to higher enzymatic solubility of treated substrates (Table 2). Oxidative degradation of rice straw and sugarcane bagasse was moreover detected near $1730 \mathrm{~cm}^{-1}$ assigned to carboxyl groups ${ }^{36}$. The peak maximum near $1730 \mathrm{~cm}^{-1}$ corresponded to the wet-lab results where $\mathrm{Fe}^{3+} / \mathrm{DHB} / \mathrm{H}_{2} \mathrm{O}_{2}$ system yielded the highest carboxyl content from oxidation of methylene groups in hemicellulose and cellulose molecules relative to other controlled experiments (Table 2). Furthermore, several possible products from partial oxidation of cellulose and hemicelluloses, i.e., carboxyl and aldehyde groups were observed as the ratio of peak integrals of 1730 to $1620 \mathrm{~cm}^{-1}$ attributed to carboxyl and aldehyde groups-to-carbonyl groups ratio, respectively ${ }^{36}$. As depicted in Fig. $1, \mathrm{Fe}^{3+} / \mathrm{DHB} / \mathrm{H}_{2} \mathrm{O}_{2}$ and
$\mathrm{Fe}^{3+} / \mathrm{H}_{2} \mathrm{O}_{2}$ reaction strongly oxidized both rice straw and sugarcane bagasse in a respective degree.

The transformation of two crystalline cellulose phases of native cellulose (cellulose I), monoclinic $\left(I_{\beta}\right)$ and triclinic $\left(I_{\alpha}\right)$ structures, was observed by means of FTIR spectroscopy. These two crystalline phases of native cellulose were differentiated based on different hydrogen bonding patterns of inter- and intra-molecular bonding within cellulose molecules ${ }^{37}$. Cellulose $\mathrm{I}_{\alpha}$ phase is metastable form and converts to more stable $\mathrm{I}_{\beta}$ phase by heat treatment or annealing at $260-280^{\circ} \mathrm{C}^{19,20}$. As illustrated in Fig. 1, vibration bands near $750 \mathrm{~cm}^{-1}$ assigned to $\mathrm{I}_{\alpha}$ crystalline form appeared for both native rice straw and sugarcane bagasse. An increase of peak intensity near $710 \mathrm{~cm}^{-1}$ indicating more stable $\mathrm{I}_{\beta}$ phase ${ }^{19}$ was observed for both rice straw and sugarcane bagasse especially after $\mathrm{Fe}^{3+} / \mathrm{H}_{2} \mathrm{O}_{2}$ and $\mathrm{H}_{2} \mathrm{O}_{2}$ pretreatment, however no correlation of $\mathrm{H}$ bonded $\mathrm{OH}$ pattens of cellulose I from the FTIR spectra was clearly found.

\section{$\mathrm{X}$-ray diffraction of pretreated rice straw and sugarcane bagasse}

The peaks in X-ray diffractograms in Fig. 2 showed intensities of the crystalline cellulose regions detected at $2 \theta=18-18.5^{\circ}$ and $2 \theta=22-22.5^{\circ}$ for rice straw and sugarcane bagasse. Hemicelluloses and lignin in lignocelluloses are considered as the amorphous parts, while cellulose was considered as the crystalline constituent. The X-ray diffractogram of oxidative pretreated rice straw samples by $\mathrm{Fe}^{3+} / \mathrm{H}_{2} \mathrm{O}_{2}$ system showed that the crystallinity index of this sample was minimum, which in turn led to highest level of enzymatic solubilization as demonstrated in Table 2. In case of sugarcane bagasse, oxidative degradation by $\mathrm{Fe}^{3+} / \mathrm{DHB} / \mathrm{H}_{2} \mathrm{O}_{2}$ system gave the minimum crys- 


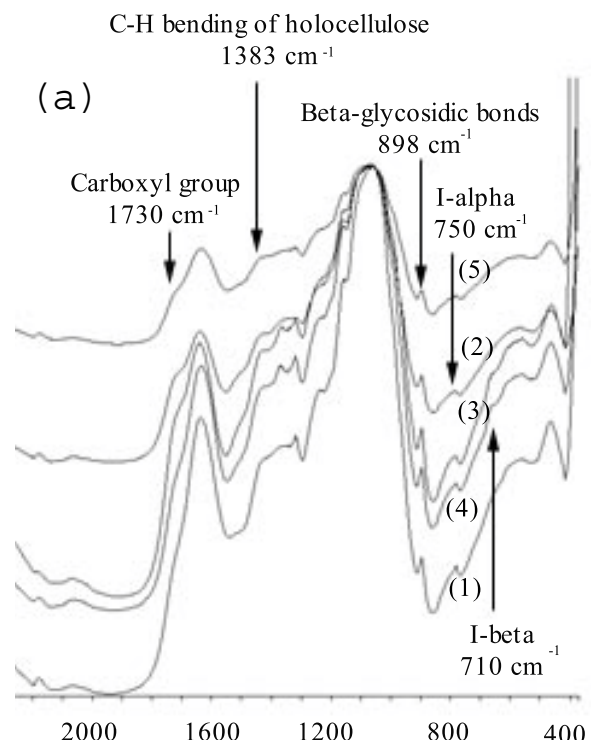

wave number $\left(\mathrm{cm}^{-1}\right)$

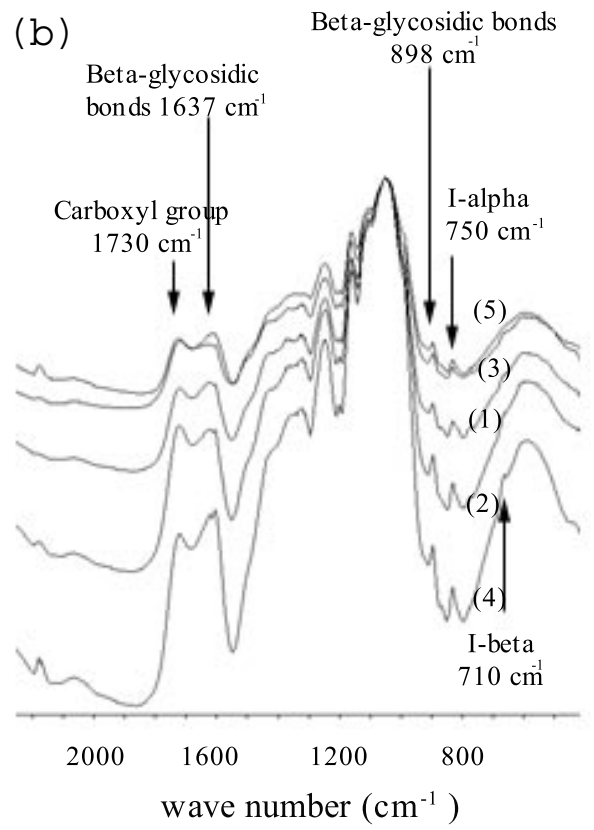

Fig. 1 FTIR spectra of (a) pretreated rice straw and (b) sugarcane bagasse by oxidative reaction and the controls; (1) untreated sample, (2) $\mathrm{Fe}(\mathrm{III}) / \mathrm{DHB} / \mathrm{H}_{2} \mathrm{O}_{2}$, (3) $\mathrm{Fe}(\mathrm{III}) / \mathrm{H}_{2} \mathrm{O}_{2}$, (4) $\mathrm{H}_{2} \mathrm{O}_{2}$, and (5) Blank.

tallinity index among all the controls tested which led to high degree of reducing sugars released after enzyme hydrolysis (Table 2). All the crystallinity results from X-ray diffractometry of amorphous and crystalline peak intensities were very well correlated with holocellulose content, weight loss and enzymatic
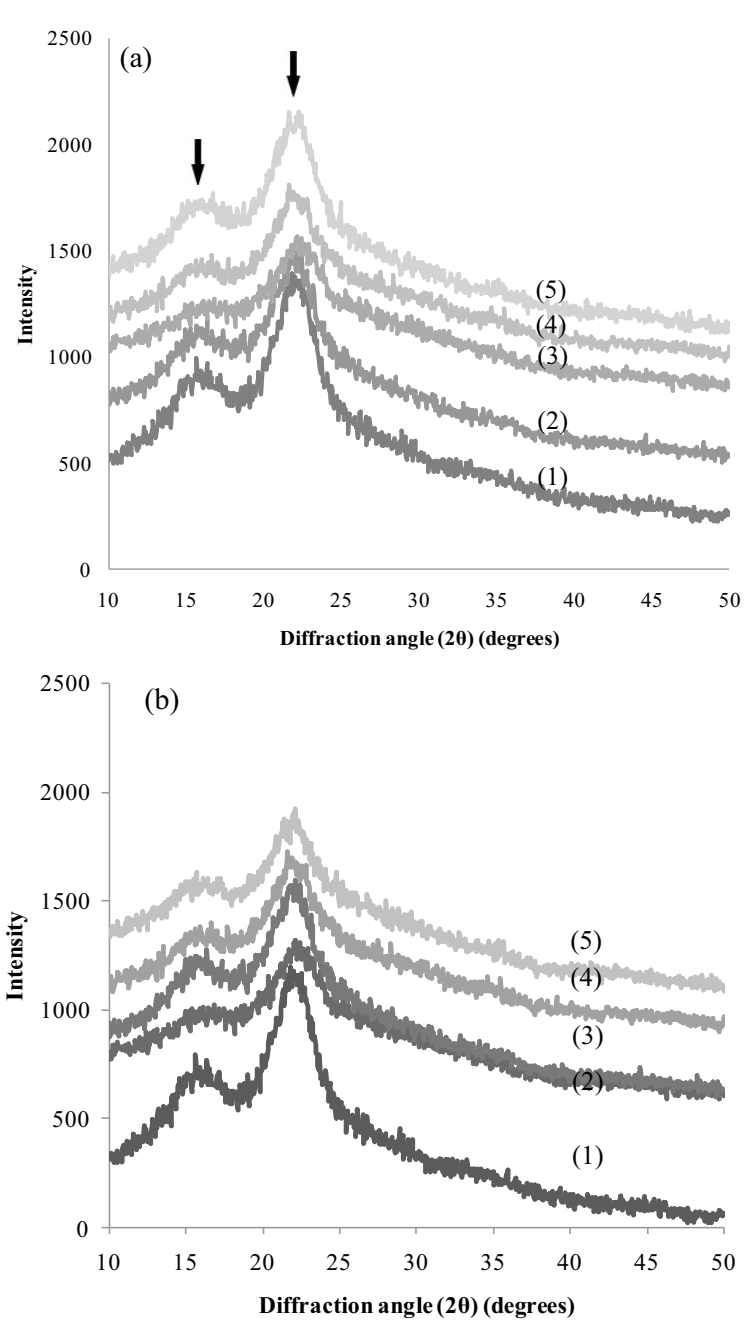

Fig. 2 X-ray diffractogram of oxidative (a) pretreated rice straw and (b) sugarcane bagasse; (1) untreated sample, (2) $\mathrm{Fe}^{3+} / \mathrm{DHB} / \mathrm{H}_{2} \mathrm{O}_{2}$, (3) $\mathrm{Fe}^{3+} / \mathrm{H}_{2} \mathrm{O}_{2}$, (4) $\mathrm{H}_{2} \mathrm{O}_{2}$, and (5) Blank.

solubilization in Table 2.

The crystallinity indices of untreated sugarcane bagasse and rice straw were $44.4 \%$ and $37.7 \%$, respectively (Table 2). This result was in accordance with another report ${ }^{38}$. Oxidative pretreated sugarcane bagasse by $\mathrm{Fe}^{3+} / \mathrm{DHB} / \mathrm{H}_{2} \mathrm{O}_{2}$ system showed the most forceful attack on crystalline cellulose region and likewise the lowest crystallinity index was obtained from this pretreatment as shown in Fig. 2b. On the contrary, dilute acid pretreatment at high temperature as well as alkaline pretreatment yielded pretreated samples with higher crystallinity index since hemicelluloses and amorphous cellulose fractions were removed leaving a more crystalline proportion behind ${ }^{39}$. Pre- 

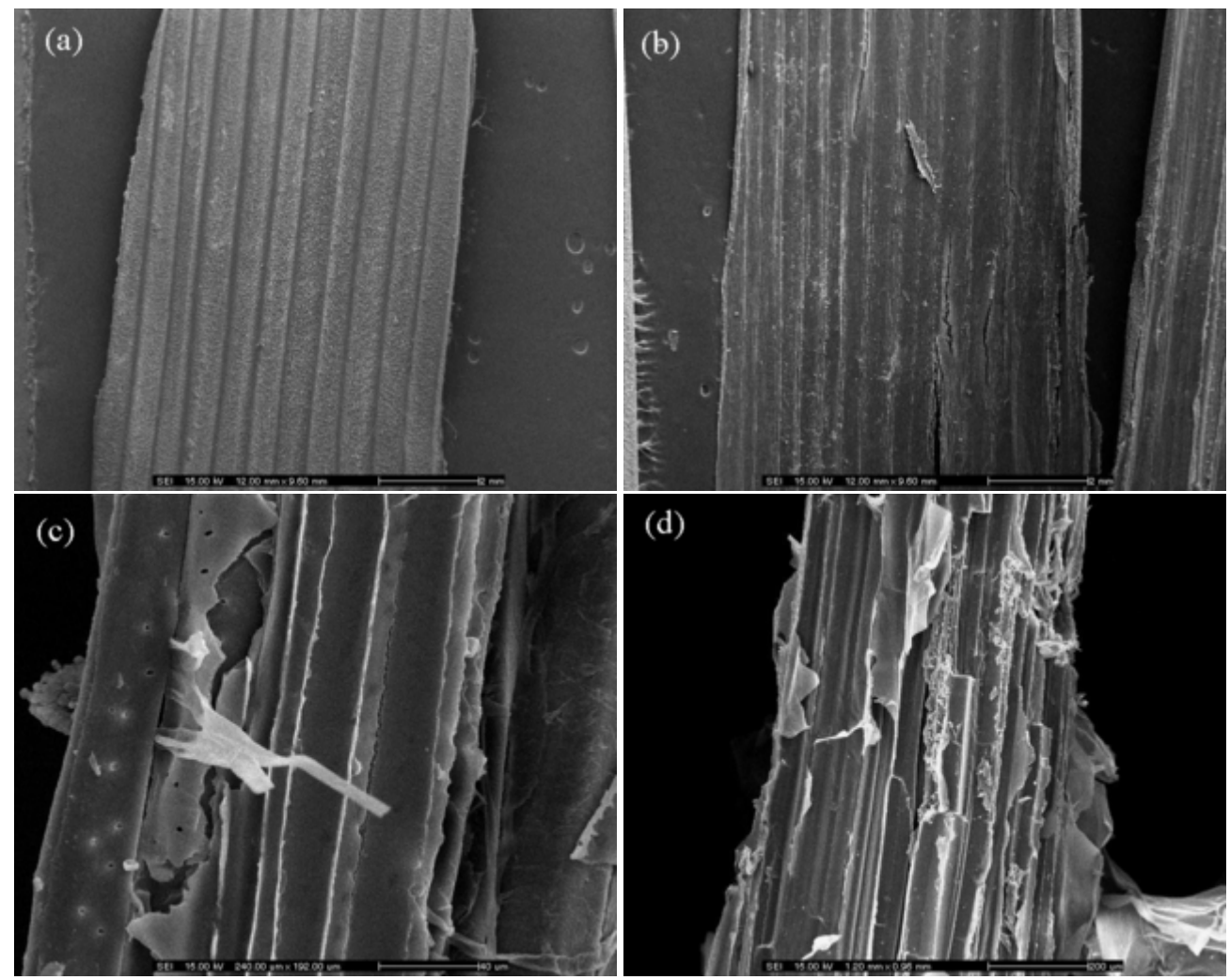

Fig. 3 SEM images of (a) untreated rice straw ( $\times 10$ magnification), (b) $\mathrm{Fe}^{3+} / \mathrm{DHB} / \mathrm{H} 2 \mathrm{O} 2$ pretreated rice straw $(\times 500$ magnification), (c) untreated sugarcane bagasse ( $\times 10$ magnification), and $(\mathrm{d}) \mathrm{Fe}^{3+} / \mathrm{DHB} / \mathrm{H}_{2} \mathrm{O}_{2}$ pretreated sugarcane bagasse ( $\times 500$ magnification).

treatment by $\mathrm{Fe}^{3+} / \mathrm{H}_{2} \mathrm{O}_{2}$ and $\mathrm{H}_{2} \mathrm{O}_{2}$ systems slightly decreased the degrees of crystallinity. The percentage of crystallinity of sugarcane bagasse and rice straw after weak acid pretreatment at ambient temperature $\left(30^{\circ} \mathrm{C}\right)$ was not obviously changed indicating that cellulosic crystal orientation was maintained in the coexistences of crystal and noncrystal areas. For rice straw (Fig. 2a), pretreated sample by $\mathrm{Fe}^{3+} / \mathrm{H}_{2} \mathrm{O}_{2}$ system yielded the lowest peak intensity of crystalline cellulose near $22-22.5^{\circ}$ representing the most rigorous attack on inter and intra-molecular $\mathrm{H}-\mathrm{OH}$ bonding of cellulose. Consequently, enzymatic solubilization was maximum for $\mathrm{Fe}^{2+} / \mathrm{H}_{2} \mathrm{O}_{2}$ treated rice straw.

\section{Scanning electron microscopic analysis of pretreated rice straw and sugarcane bagasse}

Fig. 3 shows SEM images of oxidative pretreated rice straw and sugarcane bagasse compared to untreated samples. Oxidative degradation of rice straw and sugarcane bagasse by $\mathrm{Fe}^{3+} / \mathrm{DHB} / \mathrm{H}_{2} \mathrm{O}_{2}$ system was observed on cell wall structure indicating severe attack due to diffusible highly active low molecular weight species from the reaction ${ }^{8,12}$.

\section{CONCLUSIONS}

Non-enzymatic oxidative reaction based on Fenton reaction in mild condition influenced lignocelluloses degradation. Iron mediator, DHB, showed insignificant influence on oxidative reaction of rice straw. $\mathrm{Fe}^{3+} / \mathrm{H}_{2} \mathrm{O}_{2}$ system treated rice straw achieved high delignification degree and yielded high holocellulose content with low crystallinity index and high extent of enzymatic solubilization of polysaccharides. On the contrary, DHB was required for the catalytic oxidative degradation of sugarcane bagasse, and hence $\mathrm{Fe}^{3+} / \mathrm{DHB} / \mathrm{H}_{2} \mathrm{O}_{2}$ system accomplished the favourable results on an increase of delignification and enzymatic solubilization. This biomimetic mechanistic reaction was most likely considered to occur in wood biodegradation by wood rotting fungi where amorphous and crystalline cellulose regions in wood cell wall were modified in early stages of degradation prior to the severe attack by fungal hydrolytic enzymes. The conclusion remarks were promising for development of alternative approaches for more efficient lignocelluloses use for biorefinery process in the near future. 
Acknowledgements: This study project has been subsidized by the Research Grant for the Fiscal Year 2011, Faculty of Engineering, Mahidol University, Thailand. The authors are grateful to Siam Victory Chemicals Co., Ltd., Thailand for the contribution of Accellerase 1500 (Genencor, USA).

\section{REFERENCES}

1. Srithongkham S, Vivitchanont L, Krongtaew C (2012) Starch/cellulose biocomposites prepared by high-shear homogenization/compression molding. J Mater Sci Eng 2, 213-22.

2. Krongtaew C, Onsrithong N, Suwankrua R, Jonglertjunya W (2012) Improving enzymatic saccharification of sugarcane bagasse by biological/physicochemical pretreatment using Trametes versicolor and Bacillus sp. Bioresources 7, 3935-47.

3. Martin C, Thomsen AB (2007) Wet oxidation pretreatment of lignocellulosic residue of sugarcane, rice, cassava and peanuts for ethanol production. J Chem Tech Biotechnol 82, 174-81.

4. Martin C, Blinke HB, Thomsen AB (2007) Wet oxidation as a pretreatment method for enhancing the enzymatic convertibility of sugarcane bagasse. Enzym Microb Tech 40, 426-32.

5. Chandra RP, Bura R, Mabee W, Pan X, Berlin A, Saddler JN (2007) Substrate pretreatment: The key to effective enzymatic hydrolysis of lignocellulosics? $A d v$ Biochem Eng Biotechnol 108, 67-93.

6. Krongtaew C, Messner K, Ters T, Fackler K (2010) Characterization of key parameters for biotechnological lignocellulose conversion assessed by FT-NIR spectroscopy. Part I: Qualitative analysis of pretreated straw. Bioresources 5, 2063-80.

7. Flournoy DS, Kirk TK, Highley TL (1991) Wood decay by brown-rot fungi: changes in pore structure and cell wall volume. Holzforschung 45, 383-8.

8. Goodell B, Jellison J, Liu J, Daniel G, Paszczynski A, Fekete F, Krishnamurthy S, Jun L, Xu G (1997) Low molecular weight chelators and phenolic compounds isolated from wood decay fungi and their role in the fungal biodegradation of wood. J Biotechnol 53, 133-62.

9. Wood PM (1994) Pathway for production of Fenton reagents by wood-rotting fungi. FEMS Microbiol Rev 13, 313-20.

10. Contreras D, Freer J, Rodríguez J (2006) Veratryl alcohol degradation by a catechol-driven Fenton reaction as lignin oxidation by brown-rot fungi model. Int Biodeter Biodegr 57, 63-8.

11. Schweikert C, Liszkay A, Schopfer P (2002) Polysaccharide degradation by Fenton reaction- or peroxidasegenerated hydroxyl radicals in isolated plant cell walls. Phytochemistry 61, 31-5.

12. Xu G, Goodell B (2001) Mechanisms of wood degradation by brown-rot fungi: chelator-mediated cellulose degradation and binding of iron by cellulose. J Biotechnol 87, 43-57.

13. Field JA, Jong ED, Costa GF, Bont JAM (1992) Biodegradation of polycyclic aromatic hydrocarbons by new isolates of white rot fungi. Appl Environ Microbiol 58, 2219-26.

14. Sun RC, Tomkinson J, Mao FC, Sun XF (2001) Physicochemical characterization of lignins from rice straw by hydrogen peroxide treatment. J Appl Polymer Sci 79, 719-32.

15. Billa E, Tollier MT, Monties B (1996) Characterisation of the monomeric composition of in situ wheat straw lignins by alkaline nitrobenzene oxidation: Effect of temperature and reaction time. J Sci Food Agr 72, 250-6.

16. Linxiang L, Abe Y, Kanagawa K, Shoji T, Mashino T, Mochizuki M, Tanaka M, Miyata N (2007) Ironchelating agents never suppress Fenton reaction but participate in quenching spin-trapped radicals. Anal Chim Acta 599, 315-9.

17. Blackwell J, Marchessault RH (1971) Infrared Spectroscopy of Cellulose. In: Bikales N, Segal LE (eds) Cellulose and Cellulose Derivatives, Part IV, WileyInterScience, New York.

18. Howsmon JA, Sisson WA (1954) Submicroscopic structure. In: Emill O, et al (eds) Cellulose and Cellulose Derivatives, Part I, Wiley-InterScience, New York.

19. Debzi EM, Chanzy H, Sugiyama J, Tekely P, Excoffier $G$ (1991) The $I_{\alpha} \rightarrow I_{\beta}$ transformation of highly crystalline cellulose by annealing in various mediums. Macromolecules 24, 6816-22.

20. Sugiyama J, Persson J, Chanzy H (1991) Combined infrared and electron diffraction study of the polymorphism of native celluloses. Macromolecules 24, 2461-6.

21. Stookey LL (1970) Ferrozine-A new spectrophotometric reagent for iron. Anal Chem 42, 779-81.

22. Miller GL (1959) Use of dinitrosalicylic acid reagent for determination of reducing sugar. Anal Chem 31, 426-8.

23. Wise LE, Murphy M, D'Addieco AA (1946) Chlorite holocellulose, its fractionation and bearing on summative wood analysis and on studies of the hemicelluloses. Pap Trade J 122, 35-43.

24. Zobel B, McElvee R (1966) Variation of cellulose in loblolly pine. Tappi 49, 383-7.

25. Keshk SMAS (2008) Homogenous reaction of cellulose from different natural sources. Carbohydr Polymer 74, 942-5.

26. Kataoka Y, Kondo T (1998) FT-IR microscopic analysis of changing cellulose crystalline structure during wood cell wall formation. Macromolecules 31, 760-4.

27. Segal L, Creely JJ, Martin AE, Conrad CM (1959) An empirical method for estimating the degree of crystallinity of native cellulose using the X-ray diffractometer. Textil Res J 29, 786-94.

28. Pracht J, Boenigk J, Isenbeck-Schoter M, Keppler F, 
Scholer HF (2001) Abiotic Fe(III) induced mineralization of phenolic substances. Chemosphere 44, 613-9.

29. Xu J, Jordan RB (1988) Kinetics and mechanism of the oxidation of 2,3-dihydroxybenzoic acid by iron(III). Inorg Chem 27, 4563-6.

30. Arantes V, Milagres AMF (2006) The effect of a catecholate chelator as a redox agent in Fenton-based reactions on degradation of lignin-model substrates and on COD removal from effluent of an ECF kraft pulp mill. J Hazard Mater 141, 273-9.

31. Neilands JB (1995) Siderophores: Structure and function of microbial iron transport compounds. $J$ Biol Chem 270, 26723-6.

32. Kang HK, Kim NM, Kim GJ, Seo ES, Ryu HJ, Yun S, Choi HC, Day DF, Kim J, Cho DL, Kim D (2011) Enhanced saccharification of rice straw using hypochlorite-hydrogen peroxide. Biotechnol Bioproc Eng 16, 273-81.

33. Mueller-Harvey I, Hartley RD, Harris PJ, Curzon EH (1986) Linkage of $p$-coumaroyl and feruloyl groups to cell-wall polysaccharides of barley straw. Carbohydr Res 148, 71-85.

34. He Y, Pang Y, Liu Y, Li X, Wang K (2008) Physicochemical characterization of rice straw pretreated with sodium hydroxide in the solid state for enhancing biogas production. Energ Fuel 22, 2775-81.

35. Bodirlau R, Teacas CA (2009) Fourier transform infrared spectroscopy and thermal analysis of lignocellulose fillers treated with organic anhydride. Rom J Phys 54, 93-104.

36. Łojewska J, Miśkowiec P, Łojewski T, Proniewicz LM (2005) Cellulose oxidative and hydrolytic degradation: In situ FTIR approach. Polymer Degrad Stabil 88, 512-20.

37. Atalla RH, VanderHart DL (1999) The role of solid state ${ }^{13} \mathrm{C}$ NMR spectroscopy in studies of the nature of native celluloses. Solid State Nucl Magn Reson 15, $1-19$.

38. Sindhu R, Binod P, Satyanagalakshmi K, Janu KU, Sajna KV, Kurien N, Sukumaran RK, Pandey A (2010) Formic acid as a potential pretreatment agent for the conversion of sugarcane bagasse to bioethanol. Appl Biochem Biotechnol 162, 2313-23.

39. Hsu TC, Guo GL, Chen WH, Hwang WS (2010) Effect of dilute acid pretreatment of rice straw on structural properties. Bioresour Tech 101, 4907-13. 